University of Nebraska - Lincoln

DigitalCommons@University of Nebraska - Lincoln

Faculty Publications from the Harold W. Manter Laboratory of Parasitology

6-1949

\title{
A Critical Study of North American Cestodes of the Genus Andrya with Special Reference to A. macrocephala Douthitt, 1915. (Cestoda: Anoplocephalidae)
}

\author{
Robert L. Rausch \\ University of Washington, rausch@u.washington.edu \\ Everett Schiller \\ University of Wisconsin, Madiso
}

Follow this and additional works at: https://digitalcommons.unl.edu/parasitologyfacpubs

Part of the Parasitology Commons

Rausch, Robert L. and Schiller, Everett, "A Critical Study of North American Cestodes of the Genus Andrya with Special Reference to A. macrocephala Douthitt, 1915. (Cestoda: Anoplocephalidae)" (1949). Faculty Publications from the Harold W. Manter Laboratory of Parasitology. 568.

https://digitalcommons.unl.edu/parasitologyfacpubs/568

This Article is brought to you for free and open access by the Parasitology, Harold W. Manter Laboratory of at DigitalCommons@University of Nebraska - Lincoln. It has been accepted for inclusion in Faculty Publications from the Harold W. Manter Laboratory of Parasitology by an authorized administrator of DigitalCommons@University of Nebraska - Lincoln. 
A CRITICAL STUDY OF NORTH AMERICAN CESTODES OF THE GENUS $A N D R Y A$ WITH SPECIAL REFERENCE TO $A$. MACROCE$P H A L A$ DOUTHITT, 1915 . (CESTODA : ANOPLOCEPHALIDAE)

\author{
Robert Rausch* and Everett L. Schiller \\ Department of Veterinary Science, University of Wisconsin, Madison**
}

Eight species of cestodes belonging to the genus Andrya Railliet, 1883, have been described from North American rodents. To the present time, 6 of these have been considered valid (A. primordialis Douthitt, 1915; A. macrocephala Douthitt, 1915 ; A. neotomae Voge, 1946; $A$. microti Hansen, 1947; $A$. sciuri Rausch, $1947 ; A$. ondatrae Rausch, 1948). The genus Andrya was separated by Kirschenblatt (1938) into two subgenera, depending upon the presence or absence of a prostate gland. Of the North American species, only one ( $A$. primordialis) possesses a prostate gland. Since we are concerned essentially with the other 5 closely-related species, $A$. primordialis is only briefly considered. The purpose of this paper is to present the data derived from a detailed study of morphological variation in certain of these cestodes, together with the resulting nomenclatural changes.

Testes number, testes distribution, and ventral excretory canal diameter have been hitherto considered of primary importance in the differentiation of new species. Testes distribution has been perhaps the most important single character used. In the past it has been considered possible to use these characters to separate the existing 5 species. This may be shown from the specific diagnoses, taken either from Baer's (1927) monograph, or from the original descriptions.

1. Andrya macrocephala Douthitt, 1915. Genital pores irregularly alternate. Ventral longitudinal excretory canals may attain a diameter of $320 \mu$. Testes 43 to 57 in number, situated anterior to the aporal half of the ovary, and extending beyond the aporal longitudinal excretory canals. Testes about $50 \mu$ in diameter. Cirrus sac $160 \mu$ long by $80 \mu$ wide. Eggs measure from 30 to $32 \mu$ in diameter.

2. Andrya neotomae Voge, 1946. Genital pores irregularly alternate. Testes 60 to 74 in number, confined to the space between the longitudinal excretory canals. Cirrus sac 320 to $444 \mu$ long. Eggs measure $53 \mu$ in diameter.

3. Andrya microti Hansen, 1947. Genital pores irregularly alternate. Ventral longitudinal excretory canals 25 to $41 \mu$ in diameter. Testes from 28 to 35 in number, in aporal half of segment ; occasionally a few may extend over on the poral half of the segment, but they never reach the midline of the ovary. Testes from 41 to $69 \mu$ in diameter. Cirrus sac 178 to $233 \mu$ long, by 55 to $69 \mu$ wide. Eggs measure from 32 to $33 \mu$ in diameter.

4. Andrya sciuri Rausch, 1947. Genital pores irregularly alternate. Ventral longitudinal excretory canals $30 \mu$ in diameter. Testes from 100 to 110 in number, extending on both sides beyond the longitudinal excretory canals. Testes measure

Received for publication, September 21, 1948.

* The collecting in Wyoming was made possible through a grant-in-aid from Jackson Hole Wildlife Park. Dr. Rausch is now with U. S. Public Health Service, Anchorage, Alaska.

** Parasitology Section, B. B. Morgan, Project Leader. This work supported in part by the Research Committee of the Graduate School from funds supplied by the Wisconsin Alumni Research Foundation. 
from 40 to $50 \mu$ in diameter. Cirrus sac $200 \mu$ long by $85 \mu$ wide. Eggs measure from 52 to $56 \mu$ in diameter.

5. Andrya ondatrae Rausch, 1948. Genital pores irregularly alternate. Ventral longitudinal excretory canals $85 \mu$ in diameter. Testes from 75 to 95 in number, extending over both ventral longitudinal excretory canals, and sometimes beyond the aporal canal. Testes 66 to $86 \mu$ in diameter. Cirrus sac from 213 to $224 \mu$ long by 113 to $122 \mu$ wide. Eggs measure from 33 to $39 \mu$ in diameter.

The sixth North American species, Andrya primordialis Douthitt, 1915, is readily separated from the others by the presence of a prostate gland, and by the unilateral genital pores. One of us (R. R.) recently collected specimens referable to this species from Phenacomys sp. in Wyoming; it is noteworthy that in the case of these cestodes there was some irregularity in the position of the genital pores. At present we consider this only a variation.

It is obvious from the descriptions that Andrya macrocephala, $A$. microti, and $A$. ondatrae are morphologically very similar. The recent discovery of an unusual amount of morphological variation in the cestodes of the genus Andrya parasitic in voles from a southern Wisconsin marsh has indicated that some of these species should be restudied. With this in mind, we have attempted to secure all possible Andrya material.

As far as it was possible, our specimens were fixed under comparable conditions; they were first allowed to relax in water, and then were rapidly fixed by flooding with hot formalin-alcohol-acetic-acid solution. They were routinely stained in Semichon's acetic carmine, and sections were stained in haematoxylin-eosin.

One of us (R. R.) already had a considerable quantity of Andrya material; this had been collected over the past few years from the Ohio River north to central Manitoba, and from Pennsylvania west to Wyoming. Dr. E. W. Price kindly sent us all the Andrya slides in the Helminthological Collection of the U. S. National Museum. Dr. M. F. Hansen placed at our disposal several vials of unmounted specimens of $A$. microti from Nebraska. Miss Marietta Voge loaned slides of $A$. neotomae. Dr. Reinard Harkema sent us several slides of Andrya sp. collected from Sigmodon in North Carolina. Miss Darhl Foreman provided us with a specimen of $A$. primordialis from Tamiasciurus in Wyoming, one of the hosts from which it was first described. Messrs. N. C. Negus and J. S. Findley made available for examination the fresh carcasses of a large series of mammals collected in the Jackson Hole region of Wyoming. Mr. Merle Kuns placed at our disposal a considerable amount of Andrya material from Wyoming voles. We wish to take this opportunity to thank these persons for their cooperation, without which this study would not have been possible.

\section{RESULTS AND DISCUSSION}

Of the North American species of Andrya, A. macrocephala is the most common species east of the Rocky Mountains, and occurs in a wide variety of hosts. It is an extremely common parasite of voles (Microtus $s p p$.) and was first recorded from M. p. pennsylanicus Ord by Rausch (1947). We have examined over 700 voles of this species from the North Central States region, and data on incidence and seasonal fluctuation resulting from these studies have been given in a previous paper (Rausch and Tiner, 1949). Although practically absent from voles (at least in the North 
Central States) during the winter months, this cestode reaches a peak of abundance during late July and early August. An incidence of infection of 25 per cent was observed for 64 voles examined during the month of August, 1948, from an isolated southern-Wisconsin marsh. None of the 19 animals taken after August 17 was infected, although an infected animal was taken on September 4, and another on September 8. Some of the general parasite-host ecology of this area has been discussed in a previous paper (Rausch and Tiner, 1949).

The discovery of rather extreme variation in the cestodes infecting this ecologically-isolated colony of voles (plate I, figs. 1-4) forced us to look to other characters for the separation of species of the macrocephala group. Cestodes were collected which showed variation in testes number and distribution from what is seen in Andrya microti (plate I, figs. 7-8) to that seen in $A$. ondatrae (plate I, fig. 14). In fact, testes distribution was in some cases less extensive than that seen in $A$. microti (plate I, fig. 1). On the basis of this character alone, it would have been possible to describe one or more species. A cestode from this area, collected early in 1948, was previously reported (Rausch and Tiner, 1949) as A. microti Hansen.

Since Andrya macrocephala is the common species infecting voles in the North Central States region, it was assumed that variation in this species might be much greater than hitherto recorded. The present study has shown this to be the caseit is entirely unsatisfactory to attempt to differentiate $A$. macrocephala by testes number and distribution. Moreover, it has become evident that testes number and testes distribution, along with ventral excretory canal diameter, are of little value as specific characters unless they occur in combination with other characters which are relatively constant.

Table I presents data on the variation of certain characters in Andrya macrocephala. An effort has been made to include measurements from cestodes taken over a wide geographical area, and from a wide variety of hosts.

It seems pertinent to mention the lack of eggs in the uteri of the terminal segments of certain strobilae. Although the strobila may be of normal size, and of normal development otherwise as far as can be determined, there is often a partial or complete lack of eggs. In the case of complete absence of eggs, the segments may be much elongated. When no eggs at all are present, a given cestode often cannot be identified with certainty. This sterility is common in Andrya macrocephala, regardless of host species from which the specimens are taken. That only one of 6 cestodes examined from Sigmodon contained eggs in the uteri might be taken as evidence of an unnatural host-parasite relationship. However, this situation is rather commonly observed in voles, which we consider a natural host. Although the reason for this lack of egg development is unknown, in our opinion it is not a manifestation of parasite-host incompatibility. Lack of egg development has been noted by other writers (Douthitt, 1915 ; Hansen, 1947).

In view of the results obtained, it becomes necessary to invalidate two speciesAndrya microti Hansen, and $A$. ondatrae Rausch. While these species could be considered quite distinct as long as the previous lack of knowledge concerning variation in this genus prevailed, they must now be considered identical with $A$. macrocephala Douthitt. It is unfortunate that new species must so often be described without adequate material to allow for some concept of the variation involved; how- 
ever, the difficulties in this regard are usually such as to preclude a more desirable course of procedure.

It seems justifiable now to consider Andrya caucasica Kirschenblatt, 1938, identical with $A$. macrocephala. It is a parasite of voles, and the measurements of the differential characters fall well within the range determined for A. macrocephala. A final decision cannot be made until more information, and material for comparison, is available. Andrya caucasica has been recovered from the Transcaucasus region of Russia; with this possible exception none of the species considered in this paper has been recorded outside North America.

The problem of separating the remaining species of Andrya becomes more complex, as will the differentiation of any species to be described in the future. A thorough study of our material has not disclosed any single character which could

TABLE 1.-Variation of certain characters in Andrya macrocephala Douthitt, 1915

\begin{tabular}{|c|c|c|c|c|c|c|}
\hline \multirow{2}{*}{ Host } & \multirow{2}{*}{ Locality } & \multicolumn{2}{|c|}{ Egg size } & \multicolumn{2}{|c|}{ Testes no. } & \multirow{2}{*}{ Testes distribution } \\
\hline & & range & av. & range & av. & \\
\hline $\begin{array}{l}\text { Sigmodon } h . \\
\text { hispidus }\end{array}$ & North Carolina & 26-33 & $31 \mu$ & $66-86$ & 77 & $\begin{array}{l}\text { from aporal edge of ovary across } \\
\text { aporal excretory canals. }\end{array}$ \\
\hline $\begin{array}{l}\text { Ondatra } z . \\
\quad \text { zibethica }\end{array}$ & Ohio & 33-39 & $35 \mu$ & $75-95$ & 83 & $\begin{array}{l}\text { across entire field, over excretory } \\
\text { canals on both sides; sometimes } \\
\text { beyond aporal canal. }\end{array}$ \\
\hline $\begin{array}{l}\text { Thomomys } \\
\text { talpoides } \\
\text { tenellus }\end{array}$ & Wyoming & 29-33 & $31 \mu$ & $24-40$ & 33 & $\begin{array}{l}\text { from poral edge of ovary across } \\
\text { aporal excretory canals. }\end{array}$ \\
\hline $\begin{array}{l}\text { Microtus p. } \\
\quad \text { pennsylvanicus }\end{array}$ & Ohio & $33-37$ & $\mathbf{3 3 \mu}$ & $39-54$ & 46 & $\begin{array}{l}\text { from poral edge of ovary across } \\
\text { aporal excretory canals. }\end{array}$ \\
\hline $\begin{array}{l}\text { Microtus } p . \\
\quad \text { pennsylvanicus }\end{array}$ & Wisconsin & $30-43$ & $34 \mu$ & $48-106$ & 64 & $\begin{array}{l}\text { from aporal margin of ovary to ex- } \\
\text { cretory canals; across entire field, } \\
\text { between excretory canals, some- } \\
\text { times beyond aporal canal; or any } \\
\text { distribution between these ex- } \\
\text { tremes. }\end{array}$ \\
\hline $\begin{array}{l}\text { Microtus } \\
\text { pennsylvanicus } \\
\text { drummondii }\end{array}$ & Manitoba & ster & & $\cdots \cdots$ & $\cdots$ & $\begin{array}{l}\text { from poral edge of ovary across } \\
\text { aporal excretory canals. }\end{array}$ \\
\hline $\begin{array}{l}\text { Microtus } \\
\quad \text { ochrogaster }\end{array}$ & Illinois & $30-36$ & $33 \mu$ & $\cdots \cdots$ & $\cdots$ & $\begin{array}{l}\text { from middle of ovary to aporal ex- } \\
\text { cretory canals. }\end{array}$ \\
\hline $\begin{array}{l}\text { Microtus } \\
\quad \text { ochrogaster }\end{array}$ & Nebraska & 31-39 & $\mathbf{3 3 \mu}$ & $37-67$ & 52 & $\begin{array}{l}\text { from middle of ovary across aporal } \\
\text { excretory canals; from aporal mar- } \\
\text { gin of ovary across aporal excre- } \\
\text { tory canals; also any distribution } \\
\text { between these extremes. }\end{array}$ \\
\hline $\begin{array}{l}\text { Microtus } \\
\text { townsendii }\end{array}$ & Washington & 33-39 & $35 \mu$ & $46-64$ & $\mathbf{5 5}$ & $\begin{array}{l}\text { from middle of ovary across aporal } \\
\text { excretory canals. }\end{array}$ \\
\hline $\begin{array}{l}\text { Overall averages } \\
\text { and ranges }\end{array}$ & & $26-43$ & $33 \mu$ & $24-106$ & 59 & \\
\hline
\end{tabular}

be relied upon, although it would seem that average egg size is of particular value. The 3 remaining species of the aprostate group may be characterized as follows:

Andrya macrocephala is recognized by an average egg diameter of $33 \mu$ (range: 26 to $43 \mu$ ), and by the testes usually overlapping the longitudinal excretory canals on the aporal side only. The ventral longitudinal excretory canals may be much enlarged, and when this occurs it appears to be characteristic. However, this feature may often be lacking and is perhaps dependent upon the physiological state of the worm.

Andrya neotomae is recognized by a much larger cirrus sac (320 to $444 \mu$ long), and by the fact that in combination with this the testes are confined to the area within the longitudinal excretory canals. Egg size serves to separate it from A. macrocephala, but not from the following species. The eggs range from 40 to $63 \mu$ in diameter, with an average of $53 \mu$. 
Andrya sciuri is recognized by the testes overlapping the longitudinal excretory canals on both sides, in combination with an average egg size of $52 \mu$ (range: from 43 to $56 \mu$ ). It is readily separated from $A$. macrocephala by average egg size.

Other characters not mentioned in this paper, such as scolex size, sucker development, size of strobila, etc., are of little value in separating the species of Andrya. The scolices of the species considered are figured in plate II; figures 1-5 represent the variation seen in $A$. macrocephala. Mature segments of all the North American species are figured in plate I ; figures $1-9,12$, and 14 represent $A$. macrocephala-an effort has been made to show details of worms from a variety of host species.

It should be pointed out that, while the original descriptions in all cases were consulted, our conclusions are based on data resulting from the examination of actual material. The types of all the North American species of Andrya were secured, and in all cases additional material was studied.

We conclude that no variation is brought about by the host species in which these cestodes occur. Size of host animal also does not seem important. While the specimen of $A$. macrocephala from the largest host (muskrat) was larger in size than is usually seen, specimens of equal size were taken from voles. There was no indication that multiple infections had any effect on the size of the wormhowever, rarely more than 2 or 3 worms are taken from a single host, according to our observations. Although we have not had the opportunity to study A. macrocephala in Geomys, the host from which it was described, the infections observed by Douthitt (1915) in this host were light.

There appear to be local cestode "populations" which are fairly uniform. For example, the voles near Lansing, Michigan, and Columbus, Ohio, are parasitized by cestodes which are very similar to the typical Andrya macrocephala as described by Douthitt. The southern Wisconsin specimens are extremely variable. Those in voles near Lincoln, Nebraska, appear to be morphologically rather uniform, and were described by Hansen (1947) as a separate species. It might be mentioned that except for the single specimen from the Ohio muskrat, also described as a separate species (Rausch, 1948), cestodes with unusually great testes distribution were taken only from the Wisconsin area.

Included below is a host list for the 4 North American species of Andrya. A number of host- and distribution records not previously published have been included. New records are marked by an asterisk $(*)$. Subspecific determinations of certain hosts are not included, since they were not given in the original papers.

\section{Andrya primordialis Douthitt, 1915.}

(Syn. A. communis Douthitt, 1915)

SCIURIDAE: Tamiasciurus hudsonicus ssp.-Minnesota; T. hudsonicus ventorum Allen*Wyoming; CRICETIDAE: Phenacomys $i$. intermedius Merriam*-Wyoming; Clethrionomys gapperi galei (Merriam) -Colorado; Microtus p. pennsylvanicus Ord*-Ohio, Michigan; M. pennsylvanicus modestus (Baird)*-Wyoming; M. montanus nanus (Merriam)*-Wyoming; $M$. montanus ssp.-Washington; $M$. longicaudus ssp.-Washington; M. richardsoni macropus (Merriam)*-Wyoming.

Andrya macrocephala Douthitt, 1915.

(Syn. A. translucida Douthitt, 1915; (?) A. caucasica Kirschenblatt, 1938; A. microti Hansen, 1947; A. ondatrae Rausch, 1948).

GEOMYIDAE: Geomys bursarnus Shaw-Minnesota; Thomomys talpoides tenellus Goldman*Wyoming; CRICETIDAE: Sigmodon h. hispidus Say and Ord*-North Carolina; Microtus $p$. 
pennsylvanicus Ord-Ohio, Michigan, Wisconsin; M. pennsylvanicus drumondii (Audubon and Bachman)-Manitoba; $M$. pennsylvanicus modestus (Baird)*-Wyoming; $M$. ochrogaster (Wagner)-Illinois, Nebraska; M. townsendii (Bachman)*-Washington; M. tozensendii pugeti Dalquest*-Washington; M. richardsoni macropus (Merriam)*-Wyoming; Ondatra z. zibethica Linnaeus-Ohio; Microtus socialis satunini Ogn.-Tbilsi (Georgia) Russia; Cricetulus migratorius Pall.-Tbilsi (Georgia) Russia.

Andrya neotomae Voge, 1946.

CRICETIDAE: Neotoma fuscipes ssp.-California.

Andrya sciuri Rausch, 1947.

SCIURIDAE: Glaucomys sabrinus macrotis Mearns-Wisconsin.

\section{SUMMARY}

1. A critical study of morphological variation in Andrya macrocephala Douthitt, 1915, has been made.

2. Testes distribution, testes number, and ventral longitudinal excretory canal size are considered to be of no value per se in the differentiation of the North American species of Andrya.

3. Average egg diameter appears to be a reliable character, especially in combination with the above-mentioned characters.

4. Andrya microti Hansen, 1947, A. ondatrae Rausch, 1948, and probably $A$. caucasica Kirschenblatt, 1938 , are considered to be synonyms of $A$. macrocephala Douthitt, 1915.

5. A host list, including new host- and distribution records, is included for the 4 remaining North American species of Andrya.

\section{REFERENCES}

BaEr, J. G. 1927 Monographie des cestodes de la famille des Anoplocephalidae. Bull. Biol. France et Belgique, suppl. 10, 241 pp.

Douthitr, H. 1915 Studies on the cestode family Anoplocephalidae. I1l. Biol. Monogr. 1: $1-96$.

$\rightarrow$ Hansen. M. F. 1947 Three anoplocephalid cestodes from the prairie meadow vole, with description of Andrya microti n. sp. Trans. Amer. Micr. Soc. 66: 279-282.

KirschenblatT, J. D. 1938 Die Gesetzmaessigkeiten der Dynamik der Parasitenfauna bei den maeuseaehnlichen Nagetieren (Muriden) in Transkaukasien Diss. Univ. Leningrad, pp. 5-92.

$\rightarrow$ Rausch, R. 1947 Andrya sciuri n. sp., a cestode from the northern flying squirrel. J. Parasit. 33: 316-318.

$\rightarrow-1948$ Notes on cestodes of the genus Andrya Railliet, 1883, with the description of A. ondatrae n. sp. (Cestoda: Anoplocephalidae). Trans. Amer. Soc. 67: 187-191. AND TINER, J. D. 1949 Studies on the parasitic helminths of the North Central States. II. Helminths of voles (Microtus spp.) - preliminary report. Amer. Midl. Nat. 40: 000-000 (in press) 


\section{Plate I}

Mature segments of th North American species of Andrya, with special reference to the variation seen in $A$. macrocephala. All drawings original, made with aid of a projector. The scale has a value of $1 \mathrm{~mm}$.

\section{Explanation of Plate}

Fig. 1. Andrya macrocephala from Microtus (southern Wisconsin).

Fig. 2. A. macrocephala from Microtus (southern Wisconsin).

Fig. 3. A. macrocephala from Microtus (southern Wisconsin).

FIG. 4. A. macrocephala from Microtus (southern Wisconsin).

Fig. $5 \mathrm{~A}$. macrocephala from Microtus (Illinois); similar to material upon which Douthitt's $A$. translucida was based.

FIG. 6. A. macrocephala from Thomomys (Wyoming).

Fig. 7. A. macrocephala from Microtus (Nebraska).

Fig. 8. A. macrocephala from Microtus (Nebraska).

Fig. 9. A. macrocephala from Sigmodon (North Carolina); from a strobila distorted by over-extension.

Frg. 10. A. sciuri from Glaucomys (Wisconsin).

Fig. 11. A. neotomae from Neotoma (California).

FIG. 12. A. macrocephala from Microtus (Manitoba).

FIg. 13. A. primordialis from Microtus (Wyoming).

Fig. 14. A. macrocephala from Ondatra (Ohio).

\section{Plate II}

Scolices of the North American species of Andrya, with special reference to the variation seen in $A$. macrocephala. All drawings original, made with the aid of a projector. The scale has a value of $1 \mathrm{~mm}$.

\section{Explanation of Plate}

FIG. 1. Andrya macrocephala from Microtus (southern Wisconsin).

FIG. 2. A. macrocephala from Microtus (Ohio).

Fig. 3. A. macrocephala from Microtus (southern Wisconsin).

Fig. 4. A. macrocephala from Microtus (Nebraska).

FIg. 5. A. macrocephala from Ondatra (Ohio).

Frg. 6. A. primordialis from Tamiasciurus (Wyoming).

Fig. 7. A. neotomae from Neotoma (California).

Fig. 8. A. sciuri from Glaucomys (Wisconsin). 
Rausch \& Schiller in Journal of Parasitology (June 1949) v. 35, no. 3.

Copyright 1949, American Society of Parasitologists. Used by permission.
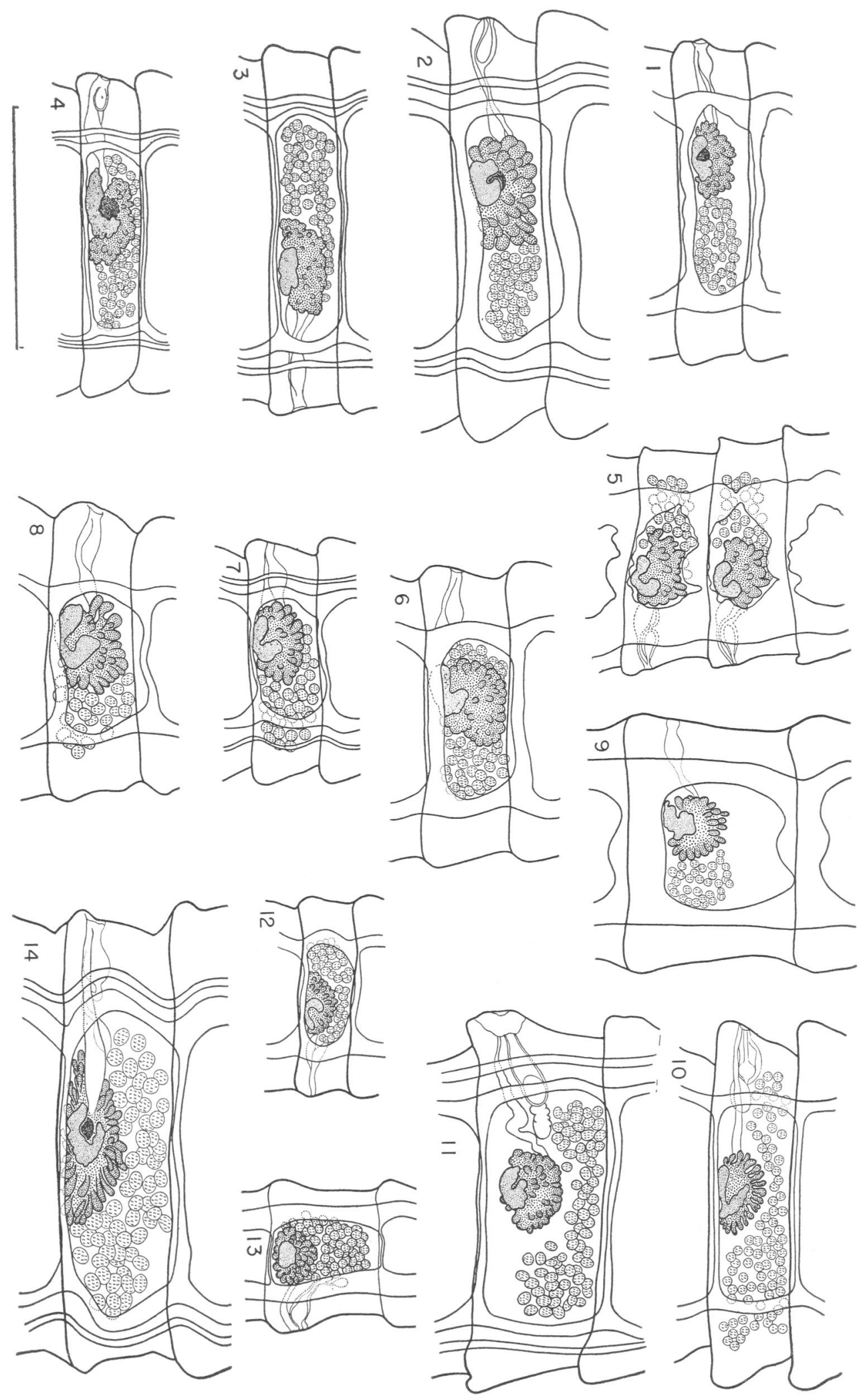
Rausch \& Schiller in Journal of Parasitology (June 1949) v. 35, no. 3.

Copyright 1949, American Society of Parasitologists. Used by permission.
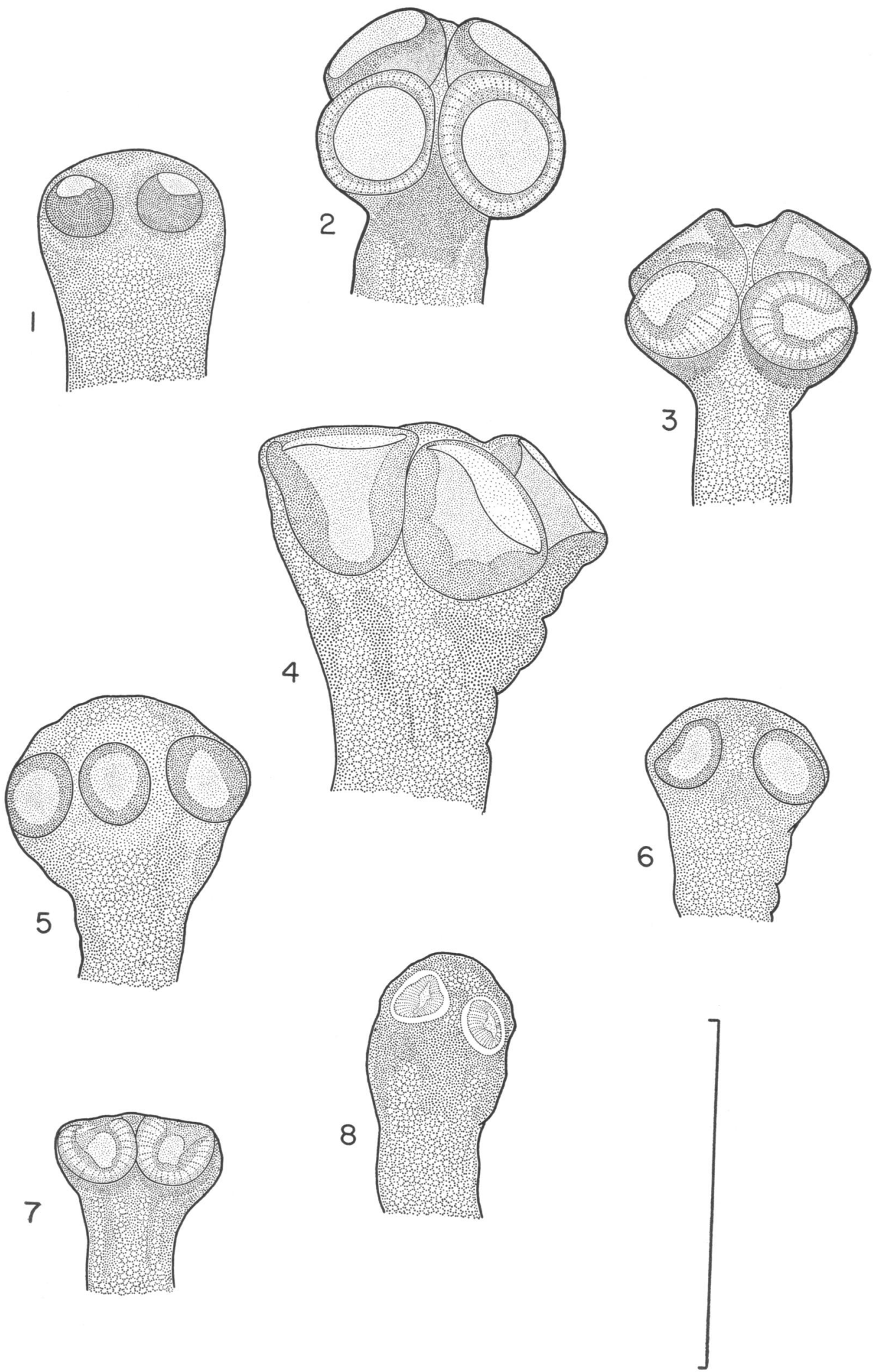